\title{
Evaluation of stain release based on image histogram analysis
}

DOI: 10.35530/IT.071.03.1641

SHAO FEN-JUAN

YAN YULONG

XU PINGHUA

FAN WEICHAO

\section{ABSTRACT - REZUMAT}

\section{Evaluation of stain release based on image histogram analysis}

In our daily life, subjective and objective method were used to evaluate the washing condition of the stain. But they have some disadvantages, such as subjectivity, special operation in laboratory, limited area, and so on. With the development of technology, the image analysis was widely used in industry. In this article, the pictures of stains before and after being washed were got through image acquisition system. And then histogram based on distance were draw and similarity of stain before and after was calculated. The similarity described the degree of washing. The higher the similarity, the more similar the image, the less stain was washed out. Two different results got from washing efficiency and image analysis were analyzed through SPSS software, the results showed that in less than 0.05 level, two groups of data had a significant correlation. This means that the image analysis could be used to evaluate the stain release well.

Keywords: stain release, washing, objective instrument, image analysis, correlation

\section{Evaluarea eficienței îndepărtării petelor pe baza analizei histogramei imaginii}

În viața de zi cu zi, se folosesc metode subiective și obiective pentru evaluarea eficienței îndepărtării petelor. Dar acestea prezintă unele dezavantaje, cum ar fi subiectivitatea, echipamente speciale de laborator, zona limitată etc. Odată cu dezvoltarea tehnologiei, analiza imaginii a fost utilizată pe scară largă în industrie. În acest articol, imaginile petelor înainte și după ce au fost spălate au fost obținute prin intermediul sistemului de achiziție de imagini. Ulterior, s-a obținut histograma bazată pe distanță și s-a calculat similitudinea petei înainte și după spălare. Similitudinea a descris gradul de spălare. Cu cât similitudinea este mai mare, cu atât imaginea este mai asemănătoare, iar pata mai puțin îndepărtată. Două rezultate diferite obținute prin eficiența spălării și analiza imaginii au fost studiate prin intermediul software-ului SPSS, rezultatele arătând că, la un nivel mai mic de 0,05, două grupuri de date au avut o corelație semnificativă. Aceasta înseamnă că analiza imaginii ar putea fi folosită pentru a evalua corespunzător eficiența îndepărtării petelor.

Cuvinte-cheie: îndepărtare petelor, spălare, instrument obiectiv, analiza imaginii, corelație

\section{INTRODUCTION}

Staining on fabric is a major concern to consumers. The evaluation of stain release has long been an important issue for researchers in the laundry and dry-cleaning industries and for others studying aspects of fabric-appearance retention [1-2].

Methods to evaluate stain release traditionally have involved visual assessment. The test used most often is AATCC Test Method 130 (Soil Release: Oily Stain Release Method) [3]. Due to the subjective nature of the rating method and the limited types of stains, the reliability and accuracy of the results are sometimes questioned [4-6]. More objective instrumental methods such as Datacolor, WSB-L and so on based on reflectance measurements and calculations are also widely used in industry. Other instrumental for example, microscopy, fluorometry, were also used in the test. All of them had some disadvantages, such as it must be tested in laboratory by special researcher and it had limited tested area [7-10]. Recently, image analysis has been applied into evaluating fabric performance, such as colour fastness, pilling, wrinkling and so on [11-17]. It could analyse the whole image of stain.

The image analysis based on the luminance histogram is used to analysis the image, but it lost many colour information. Then the colour histogram of an image is being studied. The colour histogram of an image represents the distribution of the composition of colours in the image. It shows different types of colours appeared and the number of pixels in each type of the colours appeared [18].

In this paper, standard stain cloths were being studied, such as sebum, carbon black, blood and so on. They were being washed under different washing conditions, then we analyzed the washing efficiency. We also analyzed the colour histogram of stain image which was got through Fuji film before and after being washed. The relationship between the results got by image analysis and objective instrument was discussed. 


\section{EXPERIMENTAL DETAILS}

\section{Experimental materials}

Five different kinds of stain cloth were used in our study, they were shown in table 1. Color Tester (7000A, EYE Macbeth) and Digieye Digital imaging quick rating system (d/8), England were used.

Table 1

\begin{tabular}{|c|c|c|}
\hline \multicolumn{3}{|c|}{ DIFFERENT KINDS OF STAINS CLOTH } \\
\hline No. & Stain cloth & Brand \\
\hline 106 & $\begin{array}{c}\text { Cotton soiled with IEC carbon } \\
\text { black/mineral oil }\end{array}$ & EMPA \\
\hline 111 & Cotton soiled with blood & EMPA \\
\hline 112 & Cotton soiled with cocoa & EMPA \\
\hline 114 & Cotton soiled with red wine & EMPA \\
\hline 118 & Cotton soiled with sebum/pigmen & EMPA \\
\hline
\end{tabular}

\section{Sample treatments}

The stain cloth were being washed in Front-loading Washing Machine (JW75-12SUJB, JiDe), and the washing conditions were shown in table 2. 20 groups were being discussed. During each washing, five kinds of stain $(6 \mathrm{~cm} \times 6 \mathrm{~cm})$ were sewed on the load cloth and being washed together. In order to reduce the error, five pieces of each stain cloth were placed.

Table 2

\begin{tabular}{|c|c|c|c|}
\hline \multicolumn{4}{|c|}{ DIFFERENT WASHING CONDITIONS } \\
\hline No. & $\begin{array}{c}\text { Hardness } \\
\text { of water }\end{array}$ & Load & $\begin{array}{c}\text { Dose } \\
\text { of detergent }\end{array}$ \\
\hline 1 & 50 & 1 & 20 \\
\hline 2 & 50 & 1 & 60 \\
\hline 3 & 50 & 3 & 40 \\
\hline 4 & 50 & 3 & 40 \\
\hline 5 & 50 & 5 & 20 \\
\hline 6 & 50 & 5 & 60 \\
\hline 7 & 200 & 1 & 40 \\
\hline 8 & 200 & 1 & 40 \\
\hline 9 & 200 & 3 & 20 \\
\hline 10 & 200 & 3 & 20 \\
\hline 11 & 200 & 3 & 60 \\
\hline 12 & 200 & 3 & 60 \\
\hline 13 & 200 & 5 & 40 \\
\hline 14 & 200 & 5 & 40 \\
\hline 15 & 350 & 1 & 20 \\
\hline 16 & 350 & 1 & 60 \\
\hline 17 & 350 & 3 & 40 \\
\hline 18 & 350 & 3 & 40 \\
\hline 19 & 350 & 5 & 20 \\
\hline 20 & 350 & 5 & 60 \\
\hline
\end{tabular}

\section{Washing efficiency}

Washing efficiency, a measure of the wash effect, is an important index to evaluate the quality of cleaning (equation 1). Y represented the Green primary stimulus of tristimulus values. $Y$ of the stain before and after was got through the Color Tester. And the washing efficiency was calculated as follows, the final result of washing efficiency is the average of all the result in the group.

$$
D_{r}=\frac{Y_{w}-Y_{s}}{Y_{O}-Y_{s}} \times 100
$$

In the equation, $D_{r}$ is Washing Efficiency, $Y_{w}-$ Postwash Green primary stimulus of stained fabric, $Y_{s}-$ Before-wash Green primary stimulus of stained fabric and $Y_{O}$ - Original Green primary stimulus of fabric.

\section{Image analysis}

Image acquisition was the first step of the machine vision system for the stain release evaluation. The stain cloth was photographed in a standard, black box [19]. There is a circular standard light inside the top of the box. The camera was put in the middle. In the box, there was a sample holder in the box. Then the samples were put on it to be photographed. After the images were got, they were cut into uniform size to be analyzed in the later discussion.

\section{Image processing}

The distinctive features of a stain are its colour and intensity. In order to get accurate information, the colour information was discussed. This was achieved by transforming the image from RGB plane to the I, a, b. And the colour histogram of stain image was studied via Matlab software. The average distance of each pot of the histogram was calculated. Through this, the similarity of two images before and after being washed was calculated.

\section{RESULTS AND DISCUSSION}

\section{Washing efficiency}

JMP is a common experimental design software, which is used to analysis the level of multiple factors experiment. In our study, we chose "automatic detergent on the optimization of experimental data" for analysis. As is shown in table 2, the hardness of water, dosage of detergent and the load were changed. After being washed, the washing efficiency of stains was got according to equation 1. On the surface of the stain, five small areas of both sides were tested, and the average were got. The results were shown in table 3 . The stains which were being washed under different washing conditions had different washing efficiencies. This was because those different stains had different performances, then the washing efficiencies of stains were different from each other. But for each stain, the washing efficiency changed between certain ranges. 
Table 3

WASHING EFFICIENCY OF DIFFERENT STAINS UNDER DIFFERENT WASHING CONDITIONS

\begin{tabular}{|c|c|c|c|c|c|}
\hline Group & $\begin{array}{c}\text { Sebum } \\
(\%)\end{array}$ & $\begin{array}{c}\text { Carbon } \\
\text { black } \\
(\%)\end{array}$ & $\begin{array}{c}\text { Blood } \\
(\%)\end{array}$ & $\begin{array}{c}\text { Cocoa } \\
(\%)\end{array}$ & $\begin{array}{c}\text { Red } \\
\text { wine } \\
(\%)\end{array}$ \\
\hline 1 & 29.04 & 15.32 & 54.02 & 22.58 & 29.53 \\
\hline 2 & 29.19 & 15.07 & 58.74 & 21.12 & 34.58 \\
\hline 3 & 26.78 & 12.69 & 55.00 & 15.16 & 30.44 \\
\hline 4 & 24.90 & 11.93 & 55.57 & 17.28 & 30.52 \\
\hline 5 & 17.40 & 8.73 & 48.71 & 12.32 & 26.82 \\
\hline 6 & 21.91 & 9.41 & 52.12 & 12.52 & 28.45 \\
\hline 7 & 28.27 & 13.54 & 49.16 & 18.87 & 26.43 \\
\hline 8 & 27.10 & 13.77 & 54.25 & 19.04 & 29.54 \\
\hline 9 & 22.50 & 10.12 & 45.61 & 16.11 & 22.00 \\
\hline 10 & 22.75 & 8.19 & 46.28 & 17.08 & 22.10 \\
\hline 11 & 24.59 & 11.01 & 51.01 & 13.56 & 25.51 \\
\hline 12 & 24.94 & 8.96 & 42.95 & 11.98 & 24.27 \\
\hline 13 & 17.21 & 7.15 & 43.60 & 10.43 & 23.45 \\
\hline 14 & 17.44 & 8.56 & 45.34 & 12.30 & 25.77 \\
\hline 15 & 26.21 & 14.05 & 43.98 & 19.81 & 23.34 \\
\hline 16 & 25.83 & 11.03 & 47.32 & 16.72 & 26.98 \\
\hline 17 & 23.01 & 10.14 & 41.75 & 15.07 & 24.68 \\
\hline 18 & 21.26 & 10.95 & 40.97 & 14.28 & 24.03 \\
\hline 19 & 15.54 & 7.05 & 37.54 & 9.89 & 20.23 \\
\hline 20 & 18.25 & 7.39 & 40.11 & 11.20 & 25.21 \\
\hline & & & & & \\
\hline
\end{tabular}

Image analysis

According to measurements mentioned above, the image of the stain cloth before and after being washed was got through standard image acquisition system, which was listed in experimental details. The pictures of five kinds of stains from left to right were shown in figures 1 and 2 . Figure 1 showed the five kinds of stain before being washed. Figure 2 showed the five kinds of stain after being washed. It could be seen from figures 1 and 2 that the colours of stains were changed before and after being washed.

Five pieces of each stain cloth were got, and each image was analyzed. Take one stain for example,

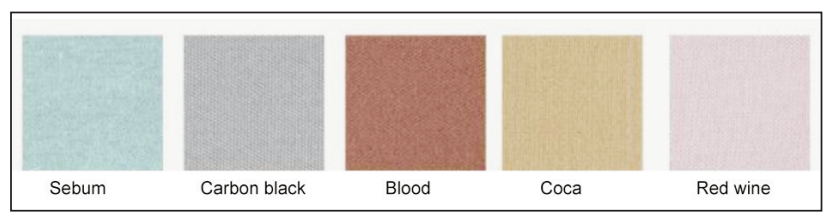

Fig. 1. Stain before being washed

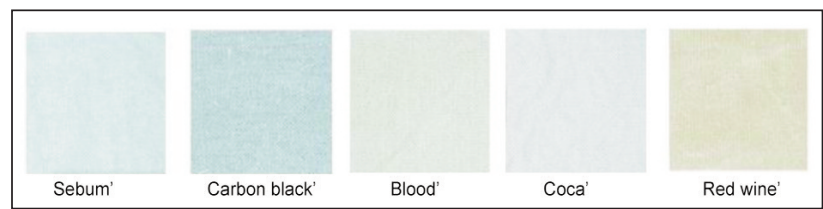

Fig. 2. Stain after being washed figure 3 showed the five pieces of blood being washed in Group 2. As is shown in figure 4, X-axis represented the value of $\mathrm{I}, \mathrm{a}, \mathrm{b}$, and $\mathrm{Y}$-axis represented the distribution at each position. We extracted the distribution of $\mathrm{I}, \mathrm{a}, \mathrm{b}$ of each image, calculated the distance of histogram of stains before (blue line) and after (red line) being washed. Then we averaged the results, the results were shown in table 4 . The value of similarity meant the degree of the similarity of two images. The higher the similarity, the more similar the image. This meant the stain was largely unwashed. The results of 20 groups were got in the same way and were shown in table 5 . It described the similarities of stains before and after being washed, which were got through the image analysis.

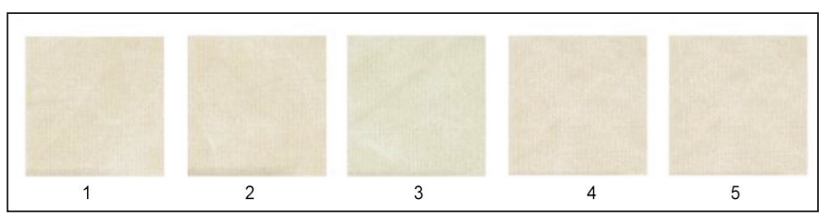

Fig. 3. Five pieces of blood of Group 2

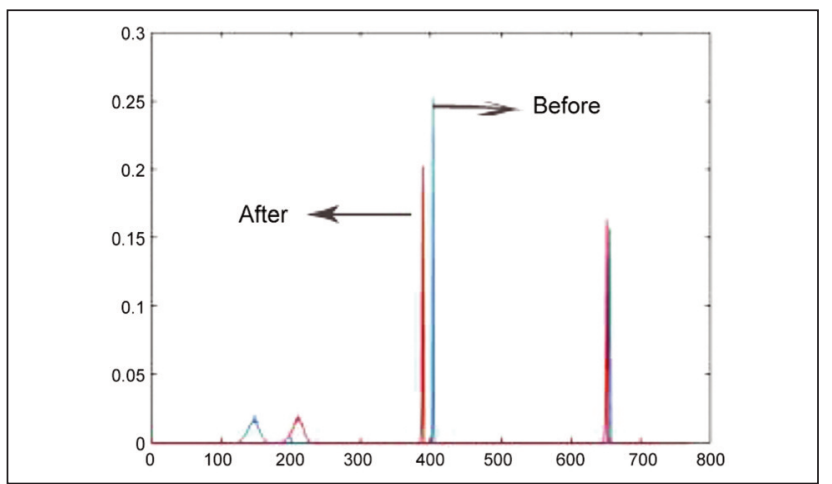

Fig. 4. Histogram distribution of blood before and after being washed

Table 4

THE SIMILARITY OF BLOOD BEFORE AND AFTER BEING WASHED

\begin{tabular}{|c|c|c|c|c|c|c|}
\hline \multirow{2}{*}{$\begin{array}{c}\text { Similarity } \\
(\%)\end{array}$} & $\mathbf{1}$ & $\mathbf{2}$ & $\mathbf{3}$ & $\mathbf{4}$ & $\mathbf{5}$ & Average \\
\cline { 2 - 7 } & 87.54 & 87.24 & 87.46 & 87.87 & 87.42 & 87.51 \\
\hline
\end{tabular}

It could be seen from table 5 that after being washed, the stain had a similarity with the original stain.

\section{Date analysis}

In order to evaluate the results of the image analysis, we use SPSS to discuss the relationship between the data got by objective instrument and image analysis. The results were shown in table 6 .

The higher the similarity, the more similar the image. This meant the stain was largely unwashed. On the contrary, the higher the washing efficiency, the more clean the stain cloth. So the Pearson correlation coefficient was negative. Table 6 showed the relationship between the data got by two different ways 
in the condition of $95 \%$ confidence interval. From table 6 , we could see that in less than 0.05 level, two groups of data had a significant correlation, the results varied from 0 to 0.030 . But the absolute value of Pearson correlation coefficient was not up to $85 \%$. It was because the image analyzed the whole image, meanwhile the certain area were taken for analysis in the test of objective instrument. In addition, the stain was uneven distributed. It could be seen in figure 3, there was white mask on the stain after being washed.

The cloths were got duty through the way of pad, there are stains on both sides of cloth. The stain was used in the test of detergent ad washing machines as standard cloth. Except this, we change the cloth, such as the material (polyester) of the cloth, the kinds of stain, and so on. We tested the cloth contained stains through painting stains on the cloth. The results of image analysis and objective instrument were coefficient.

\section{CONCLUSIONS}

The study presents a computer vision for evaluate the degree of stain release. Pictures of stains before and after being washed were got through image acquisition system and the histogram based on distance were draw and similarity of stain before and after was calculated. The similarity described the

Table 6

RELATIONSHIP BETWEEN THE DATA GOT BY TWO DIFFERENT WAYS

\begin{tabular}{|c|c|c|c|c|c|}
\hline & Sebum & $\begin{array}{c}\text { Carbon } \\
\text { black }\end{array}$ & Blood & Cocoa & $\begin{array}{c}\text { Red } \\
\text { wine }\end{array}$ \\
\hline $\begin{array}{c}\text { Pearson } \\
\text { correlation } \\
\text { coefficient }\end{array}$ & -0.511 & -0.712 & -0.598 & -0.671 & -0.498 \\
\hline Significance & 0.030 & 0 & 0.005 & 0.001 & 0.029 \\
\hline
\end{tabular}

degree of washing. The higher the similarity, the more similar the image, the less stain was washed out. The results showed that different results got from washing efficiency and image analysis had a significant correlation. The image analysis could be used to evaluate the stain release well.

\section{ACKNOWLEDFMENTS}

This work was supported by Found for daily work of postdoctoral of Shanghai (2017).

\section{REFERENCES}

[1] Kuo, C.F.J., Lee, C.J., Tsai, C.C., Using a netural network to identify fabric defects in dynamic cloth inspection, In: Textile Res. J., 2003, 73, 3, 238-244

[2] Xu, P.H., Ding, X.M., Wu, X.Y., Wang, R.W., Characterization and assessment of fabric smoothness appearance based on sparse coding, In: Textile Res. J., 2018, 88, 4, 367-378

[3] IEC 60456-2010, Clothes washing machines for household use - Methods for measuring the performance, International standard

[4] Xu, B., Reed, J.A., Instrumental evaluations of stains release in fabric, In: J. Textile Inst., 1996, 87, 1, 203-211

[5] Gururajan, A., Hequent, F., Sari-Sarraf, E.H., Objective evaluation of soil release in fabric, In: Textile Res. J., 2008, $78,9,782-79$

[6] Shen, J., Liu, J., Gao, W., Evalaution of satin release rating based on image analysis, In: Textile Res. J., 2013, 34, 3, 50-54

[7] Mao, C., Gururajan, A., Sari-Sarraf, E.H., Machine vision scheme for stain-release evaluation using Gabor filters with optimized coefficients, In: Mach. Vision Appl., 2012, 23, 2, 349-361

[8] Kuo, C.F.J., Su, T.L., Gray relational analysis of recognizing fabric defects, In: Textile Res. J., 2003, 73, 5, 461-465

[9] Kuo, C.F.J., Lee, C.-J., A back-propagation neural network for recognizing fabric defects, In: Textile Res. J., 2003, $73,2,147-151$ 
[10] Celik, H.I., Dulger, L.U., Topabekiroglu, M., Development of a machine vision system: real-time fabric defect detection and classification with neural networks, In: J. Textile Inst., 2014, 105, 6, 575-585

[11] Bugao, X., Evaluation of color alterations on fabrics by image analysis, In: Aatcc Review, 2009, 37-42

[12] Goncalves, P.L.S., Furtao, H.A.M., Morato, J.P.F.R., Goncalves, M.A.C., Automatic fabric inspection by machinevision, applying simple algorithms, In: Machine vision application in industrial inspection, 2002, 4664, 198-206

[13] Hu, Y., Long, Z., AIRegib, G., A high-speed, real-time vision system for texture tracking and tracking and thread counting, In: IEEE SIGNAL processing letters, 2018, 25, 6, 758-762

[14] Deng, D., Wang, R., Wu, H., Learning deeping similarity models with focus ranking for fabric image retrievals, In: Image Vision Comput., 2018, 70, 11-20

[15] Li, C., Gao, G., Liu, Z., Fabric defect detection based on biological vision modeling, In: IEEE ACCESS, 2018, 6 , 27659-27670

[16] Koya, Y., Yue, B., Nakata, T., Araki, M., Vision inspection automation for yarn breakage of warp knitted fabric, In: Transactions of the society of instrument and control engineers, 2017, 53, 2, 134-143

[17] Hill, M., Kamalakannan, S., Gururajan, A., Dimensional change measurement and stain segmentation in printed fabrics, In: Textile Res. J., 2011, 81, 16, 1655-1672

[18] Ghosh, A., Guha, T., Bhar, R.B., Pattern classification of fabric defects using supports vector machines, In: International Journal of clothing science and technology, 2011, 23, 2-3, 142-151

[19] Xuemei, D., Hong, L., Pinghua, X., Xiongying, W., Objective evaluation methods based on the visual perception of washing device about detergency, 2016109125764

Authors:

SHAO FEN-JUAN ${ }^{1}$, XU PINGHUA ${ }^{2}$, FAN WEICHAO ${ }^{1}$, YAN YULONG $^{3}$, DING XUEMEI ${ }^{1,2}$, WU XIONGYING ${ }^{1,3}$

${ }^{1}$ College of Fashion and Design, Donghua University, 200051, Shanghai, China

${ }^{2}$ Key Laboratory of Clothing Design \& Technology, Donghua University, Ministry of Education, 200051, Shanghai, China

${ }^{3}$ Shanghai customs district, 200002, Shanghai, China

Corresponding author:

DING XUEMEI

e-mail: fddingxm@163.com 